\title{
Speech Disfluency Made by Male and Female Learners at Kampung Inggris Semarang
}

\author{
Dhanan Abimanto1, Yayuk Hidayah ${ }^{2}$, Lili Halimah³, Umar Al Faruq A Hasyim \\ ${ }^{1}$ Universitas Maritim AMNI Semarang, Indonesia \\ 2Universitas Ahmad Dahlan Yogyakarta, Indonesia \\ ${ }^{3}$ STKIP Pasundan Cimahi, Indonesia \\ ${ }^{4}$ Institut Agama Islam Ma'arif NU Metro Lampung, Indonesia
}

dhananabimanto@unimar-amni.ac.id*

\begin{abstract}
In utterance, there must be some disfluency whether in normal people or in stutterer. Moreover, the disfluency would be different if it was categorized into two based on the gender. The researchers' figures out the disfluency based on the gender, male and female. The article was to find out any types of disfluency that appear on the male and female speeches, to find the dominant type of disfluency occured in male and female speeches, the difference between male and female speeches, and the factors causing the disfluency made by male and female speeches. The sample was 24 English learners at Kampung Inggris Semarang, 12 males and 12 females. In collecting the data the researchers used observation and interview. In analysing the data, the researchers used the theory from Clark and Wasow supported by Johnson and Bortfeld et.al. The result showed that nine types of disfluency occur in learners' speech, i.e filler, silent pause, revision, incomplete phrase, broken word, repetition, grammatical disfluency, prolongation, and false start. The dominant disfluency occured in male and female speeches was filler. In the dominant disfluency, males produced more filers than females, whereas silent pause was more produced in female speeches. Besides, there was some factors causing disfluency made by male and female learners of Kampung Inggris Semarang, which were related to psychological factors. It included cognitive factors and affective factors. In total, male produced more disfluency than female. Besides that male learner made more factors which could affect the disfluency in their speeches than female learners, male learners were more likely not in mastering grammar and vocabularies and getting prepared in materials.
\end{abstract}

ARTICLE INFO

Article history:

Received

March 08, 2021

Revised

April 13, 2021

Accepted

April 16, 2021

How to cite

Keywords: Speech Disfulency, Factors Speech Disfluency, Disfluency Abimanto, D., Hidayah, Y., Halimah, H., \& Hasyim. U. (2021). Speech Disfluency Made by Male and Female Learners at Kampung Inggris Semarang. Anglophile Journal, 1(2). p.42-56. https://dx.doi.org/10.51278/anglophile.v1i2.21

This is an open access article under the CC BY SA license https://creativecommons.org/licenses/by-sa/4.0/

Published by CV. Creative Tugu Pena

\section{INTRODUCTION}

As a language learner, fluency in speaking, especially in second language, can signify that a learner is able to get the knowledge of learning language. It is because speaking in another language is quite difficult to learn for foreign learners. The learners have to practice all time so they can be used to speak fluently in target language that they learn. The ability to produce how to speak is called speech. Speaking is actually related too to speech production which seems require very little thought or effort. However, it does not seem as easy as thought (Tumanova et al., 2014). Fauziati (2013) states that effortless of 
producing a speech is not true. There are two major sources of speech disfluency which are disfluency caused by the difficulties in planning and executing speech and disfluency caused by the difficulties of articulatory muscles performing sounds (Clark, H. H. \& Wasow, 1998). However, there is a condition that can be called as speech with no disfluency and runs smoothly; that is ideal delivery (Lickley, 2017). The ideal delivery can be considered fluent speech that speakers execute all the clauses in a single fluent series. The fluency of speech itself, however, can be affected by several factors such as age, relationship between speaker and interlocutor, topic, role, and gender (Bortfeld et al, 2001). It is similar to Muamaroh's study (2013), she proposes that mastering vocabularies, structure and material can improve their confidency in speaking English. Besides, the topic that the learners familiar with is also related to the disfluency that the learners produced in their speech.

According to Adams (1990), fluency of speech in second language is also affected by some factors. The factor may be the speaker's ability of speech production. Besides, syntactic complexity and discourse complexity also influence the fluent production of speech (Sadri Mirdamadi, F., \& De Jong, N. H. 2015). When complexity increases, the demands for the production of fluent speech may exceed the individual's abilities; therefore, fluency may be compromised. However, the difficulty of the speaker's ability in producing their speech is commonly called speech disfluency. Spontaneous human speech is notoriously disfluent. Speakers hesitate, interrupt mid-phrase or mid-word, repeat or replace words, abandon phrases to start afresh, and express their talk with expressions like um, uh, or, I mean, and oh. (Brennan, 2000) Speech disfluency occurs because someone probably losses language production of first language when the speaker moves to a second language (Byrd, C. T., Bedore, L. M., \& Ramos, D.(2015). Speech disfluency are distinguished as being either linguistic disfluency or stuttering disfluency. All individuals produce linguistic disfluency in speech; however, if they are produced frequently, linguistic disfluency may indicate difficulties with utterance formulation or word finding (Miller et al., 2005). Linguistic disfluency also happens to normal people who do not have disability to speak. On the other hand, stuttering disfluency only happens to stutterer or people who are difficult to speak because of brain's problem. Speech Disfluency, Clark and Wasow (1998) propose that there are several types of disfluency such as filler, silent pause, repetition, prolongation, hesitation, grammatical error, and false start. Johnson (1961) proposes hesitation consists of incomplete phrase, revision, and broken word. However, the occurrence of disfluency itself sometimes is different based on the gender. According to Shriberg (1994) and Shriberg (1996) in Bortfeld et.al (2001) states, "Men produced more fillers than women did, but the sexes were equal with respect to other types of disfluency rates."

Ironically, speech disfluency happens to learners who take English as a major study in their college. In fact, they are difficult to speak English fluently. They do not speak English very well although they have been studying English for years and practicing all days to speak in English. The speech disfluency that they make could be a hesitation, repetition, or just filler in their English communication. In Corley and Stewart (2008), Beattie and Butterworth states that fillers occur when frequency is held constant and the speakers might be aware of an element of choice in selecting words with low contextual probability, and were more likely to be disfluent for this reason.

Due to Indonesian people are not very familiar in spoken English, it is difficult to find them. Fortunately, there are some courses that provide the English learning through experience of how English is applied in spoken communication. One of the courses that gives the method in learning English by using it in daily activity even in speaking is Kampung Inggris Semarang. Kampung Inggris Semarang is an institution which runs in education field. It concerns on an effective and fun English learning. In this research, Learners who are learn in it are taken as subject of the research. 
In Kampung Inggris Semarang, there are some cases that attract the writer to analyze further. There are varied cases from the types that often appeared in the speech to the difference of frequency of disfluency made by male and female learners. Even though they use English intensively and structurally, they even made disfluency in speaking especially fillers, such as "when -uh -uh I join..." and repetition such as "I-I-I study in -in -in

..." However, there are other disfluency types made by the learners but it is not as much as the above two disfluenciy, like prolongation such as "It is intereti----ng when..." which happens about 1-2 seconds. There is also a case showed that female learners have fewer disfluency than the male learners. There must be some factors that make different between male and female learners. It interesting enough when reviewing the case in Kampung Inggris Semarang that male produced more disfluency than female. However, Bortfeld et.al (2001) has ever studied this topic about disfluency just like stated before, but they did not focus on the gender's case.

Based on the explanation above, speech disfluency based on the gender would be interesting to research further. Therefore, the correlation between this current research to the previous researches that have been studied is to compare and to prove whether the previous research and the current research are similarly correlated or not. In addition, this research more focuses on the disfluency made by male and female learners. The writer conducted the research about the differences of the type disfluency occurred in male and female learners. This study is also hoped to be the useful study for other researcher to conduct further about the disfluency. Concerning on the research problem above, the research is conducted is to know the types of the disfluency, the dominant of the disfluency, factors causing disfluency made by male and female learners, and the difference of disfluency made by male and femlae learners.

\section{METHODS}

The research uses descriptive qualitative method. The subject of the research is the 24 learners of Kampung Inggris Semarang which is classified by gender, 12 males and 12 females and their age are between 19-24 years old. The participants who are also the subject of the study are learners who belong to the intermediate learners in Kampung Inggris Semarang. They have been studying in there from 1-2 weeks. The participants are from the different backgrounds such as college learners, workers, etc. and they come from different places. However, the same thing of them is they are the English learners as EFL learners.

The researcher in this case belongs to the non-participant observer; thus, the observation used in this study was called non-participant observation. Technically, in collecting the data in the observation, the participants are asked to deliver the monologue/speech which contained the topic which has been given in 3-5 minutes. In addition, the researcher conducts the interview to get the answer of the factor influencing disfluency. The researcher used this method aiming to explore the factors that affect the disfluency made by learners. The researcher made some purposive questions to know the problem such as the habit of using English in daily activity. For this study, the researcher follows the Creswell's theory in collecting data especially in interview which is the researcher does the unstructured and open ended interview then the researcher takes interview notes.

To make easier transcribing the data especially in analyzing the disfluency contained in utterances that were delivered in monologue, the researcher uses ELAN software. The term of transcribing in ELAN software is changed to annotating. However, the researcher assessed the data during and after collecting data. The researcher analysed the data based on the observations by annotating or transcribing, categorizing it into several categories and formulating the result into useful findings. To annotate the data, the researcher needs software to analyze the data, namely ELAN. It is a multimedia annotator 
used to annotate the audio-visual data. It is one of the language tools of Max-PlanckInstitute for Psycholinguistics. The project files of ELAN are stored in XML format, which is one of the universal storage formats for computer science. It is an open source and it is both editable and upgradeable. The second step is Reading and understanding the data. However, there are lots of difficulties involved in annotating disfluency because the data are utterances containing words and sentences do not have clear boundaries as in written language. The last step in this step the researcher prepared guide-lines for annotating disfluency.

\section{RESULT AND DISCUSSON}

There are some findings that can be described in this chapter. In the research the researcher has found some interesting findings that can be the further discussion in the future research. However, the resaerch in the researcher's study provides some things according to the research problems that the researcher wanted to figure out.

\section{The Type of Disfluency Made by Male and Female Learners}

In the research, the researcher found several type of disfluency made by male and female learners, such as filler, silent pause, repetition, prolongation, hesitation that includes revision, incomplete phrase, and broken word, false start and grammatical error. However, in the research there is one disfluency type that never appeared in the speeches i.e. slip of tongue. The temporary reason why the learners never produce slip of tongue because learners still have lack of mastering vocabularies and grammar. In this case, it can be said that it is about lexical storage. As Seliger (1980) in Poulisse (1999) states that slip of tongue relates to lexical storage. That is why the researcher has an assumption that lexical storage and the lack of vocabularies and grammar have correlation. Logically, if someone has no lexical storage, he/she would be less in making mistakes about lexical stuff like vocabularies and grammar.

\section{Filler in Male and Female Learners}

There are 445 times of FLs occured in all learners' speeches. Learners started to made frequently after the minute 0,25 . It gradually increased until the minute 1,00 . And at the time of minute 1,25, the occurence of FL decreased, but it later increased after that. However, in the minute 1,75, number of FLs started to decreased and gradually declined in number. Meanwhile, the frequency of FL in male learners shows the greatest frequency of disfluency in male learners' speeches, which is shown $41,63 \%$ or it can be said that 291 times of Fls occured in male learners. Whereas, in female learners 32,35\% which is 154 times of occurrence. The example of FLs made by all learners are served below along with the analysis of FL. They started to make FL such as $u h$, um, well for several times such as:

\section{a. "It is [um] suitable with the characteristic."}

b. "There are [um] more advantages than disadvantages."

In example (a), the expression "um" was used in the utterance of the speaker. The speaker made FL while he tried to find the proper word after he produce "it is". He probably thought hard to find the worrds "suitable with the characteristic". In example (b), like (a) the speaker tried to find the words "more advantages than disadvantages". In example (c), it is different with other examples, the expression was used is "well". It is also considered as FL while expression "well" is actually does not neccessary to use.

\section{Silent Pause in Male and Female Learners}

SPs in learners' speeches are different in each learner. It sometimes occured the middle of utterance or in the last of utterance. It occasionaly occured in the beginning of utterance and rarely occured i the last of utterance. The occurence of SPs gradually increased until the minute of 1,50 . However, the rate of SPs finally decreased after the minute of 1,50 after that. It means that SPs occured in the middle of the speech while the speakers deliver the speech. SP commonly occured in male learners, its frequency shows $32,76 \%$, which happens 229 times of occurrence, whereas in female learners shown 
$38,66 \%$ which happens 184 times of occurrence. The examples of utterances found in thee research:

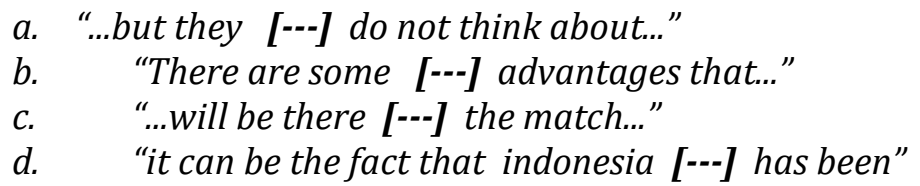

As the example (a), SP occured in the middle of the utterance after the speaker said the subject "they" and delayed for a while before he continued the wanted words. It indicates that the speaker was thinking some proper words that he wanted to say, but he could not say directly right after he produced wrd "they". In example (b), the speaker was probably thinking about the proper word after she said "there are some", but she delayed for a while to choose the words that were actually suitable for the previous words. Finally, she produced the proper word she wanted to say "advantages...". Uniquely, while she made this delay, she made a gesture by moving her hand repeatedly. In addition, in example (c), the writer presumes that the speaker was blank for a while, that he wanted to choose a proper word. Presumably the speaker experienced loss of production speech for a while, he did not know the word that would say after he said "will be there", but he can fially found the wanted word i.e. "the match". As previous examples, in example (d), presumably the speaker was blank for seconds in producing the next word to utter "has been"after he produced "it can be the fact that indonesia". It indicates that the speaker was difficult to find the next proper word. All the findings prove that SP probably happens due to the delay of formulating words in utterance.

\section{Revision in Male and Female Learners}

This kind of disfluency usually appeared in the midle of learners' speeches. the occureance approximately appeared thirty seconds after the speaker started uttering. RVs started to appear in the minute of 0,5 , and then gradually increased until the minute of 1,00 . Then it started to decreased in number after the minute of 1,25 . RVs began to increased again in the mnute of 2,0 and finally decreased after that. As the findings found, the occurence of RVs belongs to the disfluency type that occured rarely. The occurrence of $\mathrm{RV}$ is $2,15 \%$ which happens 15 times $\mathrm{n}$ male learner's utterance, however, in female learners, it happens differently, its occurrence is 2,31\% which happens 11 times. RV that usually appeared in learners' speeches are as follows:

a. "when [I wait for--][when I waited for] about two weeks."

b. " [there is--][there are] several things that..."

In (a) the speaker intended to say "when I waited for" but due to the hesitation, he made a disfluency i.e. revision which he repaired immediately after he recognized the error. In (b) the speaker recognized that she made an error by saying "there is", but later she repaired immediately with other phrase "there are". From two cases above, it indicates that RV in the utterance is reparation of phrase that the speaker did while he/she made an error. As stated by Johnson (1961) in RV, the speaker still continued the IP with the phrase that speaker says, so the cohesion of the sentence structured and it usually occurs because of grammatical error. Therefore RV is revised word or phrase that are related to grammatical error.

\section{Incomplete Phrase in Male and Female Learners}

IP is different with RV. IPs occured after the minute of 0,75 . However, the occurence of IPs does not too significantly often occured. There are few occurence of IPs in speeches. There are only 18 of occurence in all speeches. however, IPs usually appeared in the middle of speech both male and female learners but started to decrase after the minute of 1,25 and gradually decrease until the minute of 2,0 and began to increase again in th eminute of 2,75. Uniquely, IPs began to disappear after that. The frequency of IP in male learners is different with female learners. In male learners its frequency is $1,43 \%$ or 10 time of occurrence, while in female learners it is $1,68 \%$ or 8 times of occurrence. The 
examples of IP that are found in the study such as " [I will--] want to say...". Seeeing the examples above, such as in the utterance (1), the speaker was actually intended to say "want to.." but she accidently said "I will", It means that in the plannng load of the speaker is phrase "want to" but she made a mistake instead by saying "I will". She repaired the unwanted phrase by the new phrase that she actually wanted to say. It can be proven by the Johnson's theory. As stated by Johnson (1961) the speaker does not continue the IP like RV. RV happens when a speaker made an disfluency of IP but he/she repeats the phrase and revise it.

\section{Broken Word in Male and Female Learners}

BW began to start in minute 0,5 then it increased gradually until minute 1,5 . But then it began to decrease until in minute 2,25. In male learners its frequency shows $1,29 \%$ or 9 times of occurrence, whereas in female learners, its occurrence shows 2,10\% or 10 times of occurrence. According to Johnson (1961) BW is typified in which the normal rhythm of the word is broken in a way that definitely interferes with the smooth flow of speech.

a. "[The-] then we can use the facilities..."

b. "How the [gov-] government handle this traffic jam."

As in the example (1), BW occured in the beginning of utterance. There are two assumption about the analysis of this case. First, the speaker intended to utter "then" but she made an error that she uttered another word "the" by repeating it in another version of completed word "then". Second, the speaker was actually wanted to say the word "the", but she finally repaired after it becoming the word "then" perhaps she has a hestitaion while she uttered it. It indicates that the word "the" was really intended word but it was not suitable for the words that she wanted to utter. In (2), unlike (1), the speaker really made hesitation in uttering word "government", so he made BW in his utterance which resulted word "gov".

\section{Repetition in Male and Female Learners}

$\mathrm{RV}$ often occured in the middle of the speech at the minute of 1,50. But it began to decreased at the minute of 2,25. Its frequency is 8,44\% which happens 59 times of occurrence in male learners, while in female learners is $9,24 \%$ or 44 times of occurrence. However, in the word REP itself, there were three kinds of it which occurred in the learners' which are part-word REP, 1 unit of word REP, and 2 units of word REP. Those three kinds of REP on occurred like in the utterance below.
a. Part word REP
" [coc-] cocaine"
b. 1 unit of word REP
"... some [point--] point of view."
c. 2 unit of word REP
"There [there-- there--] are some examples that..."

The occurrence of word REP even occurred together in the one utterance which happened the combination of 1 unit and 2 unit of REPs, such as in the utterance, "...we can find [flower--] flower [in-- in--] in everywhere." Besides, the other REPs occured in the study is phrase repetition and it were made by the learners in all the utterances. In addition, most phrase REP occurred along with filler. The characteristic that the writer found in this disfluency is FL happens in the middle of repeated words, such as:
a. " there is crime in internet-- [uh] [crime in internet...]"
b. " how to-- [um] [how to] become a friend."
c. "I have-- [uh] [I have] seen my neighbor.."

There was even a case that REP occured along with one more disfluencys i.e. FL, and the REP occured in two unit of REP which is in word and phrase form, such as in an utterance "[We come to--] come [uh] [we come to] office, may be." However, there was 
another characteristic that occurred in this disfluency type. Most of that, repetitions occurred along with the PRO before the last repeated full word or phrase but it did not occurred in the part word REP. The utterance below are the examples of REP that describes REP can happened along with PRO.

a. "When [I [I--] I] have an experience"

b. "We [we [we--] can do better for..."

PRO does not certainly happened in the second word that he speaker utter, as stated above, PRO can happen in the last repeated word.

\section{Prolongation in Male and Female Learners}

This type was found in all learners' speeches. PRO occurred 50 times in all the learners' speech. PROs can occur in th ebeginning of the speech especially in this study occured at the minute of 0,5 . And then it beagn to increased graduyally until the minute of 1,50. But the number of PROs began to decrease after it. In male learners its frequency is $4,29 \%$ or 30 times of occurrence, while in female learners $4,20 \%$ or 20 times of occurrence. PRO usually occurred in the one syllable word such as "and", "is", "you", and "to". The rate of PRO made by the learners could reach about 2 seconds.

In the speeches, PRO occurred because learners who made PRO had difficulty organizing the speech production. Therefore, the learners made a delay in word by making long pronunciation. However, there was the occurrence of PRO that appeared along the other disfluency, FL. The order of the occurrence was PRO - FL. It occurred as stated in the utterance:

\section{a. "I think teacher [is ---] [uh] a noble job."}

b. " $[\mathbf{y o}-\mathbf{u}][\mathbf{u h}]$ need teacher..."

In the example (a), the speaker made two disfluencies i.e. PRO and FL, the speaker presumably wanted to say "noble job" but the speaker experienced the gap while producing the next word, so she made disfluency in utterance. the speaker was intended to prolong the word because he was also thinking and finding the word to fill the next word. So in the utterance he prolonged the word. But unfortunately, he could not managed to find the next proper word so he made FL with expression "uh". In (b) PRO occured in the beginning of utterance, the speaker made this disfluency in the first she uttered. As the previous example, the speaker probably wanted to say "need teacher" but she faced the difficulty in producing word. So she made PRO and FL at the same time.

\section{False Start in Male and Female Learners}

The type of this disfluency occurred only 12 times in the all learners' speeches. FS appeared in the beginning of the learner's utterance. FSs begins to appear at the minute of 0,50 .the occurence was fluctuative. It never happen in the early of the speech an $d$ it begins to decrease and disappear at the minute of 2,75 . In male learners its frequency is $1,14 \%$ or 8 times of occurrence, while in female learners $0,84 \%$ or 4 times of occurrence. It occurred in the utterance when the learner made an disfluency in pronouncing the part word or making the incomplete word without any continued word. As the definition of false start stated by Vural (2008) \& Yu, L. (2019), recollecting wrong words from the memory and starts new sentences with a wrong word or words, False start always happens in the beginning of utterance. The example of FS that occurred in the learners' speeches is as follows:

\section{a. "[and-] because my throat.."}

b. " [Although they-] but we are as learners can..."

In (a), the speaker made an error by saying "and", she started saying "and" and she recognizes that it was unneccessary. So she continued with new word without completing the previous word and directly said "because my throat..". in (b), like (a), it can be presummed that the speaker intended to say "but we are as learners can..." but he recognized that he made an error by saying "although they" so he repaired without 
completing the words but produced new words. In the findings there are some cases that FS is followed by FL, such as in the utterances:

c. " [in-] [uh] so I think.."

d. "[that is one of] [uh] there is an example of punisment that..."

In (c), the speaker made false in utterance but he recognized that he made "in" but then he suddenly made new words to fill the next words without completing the previous word "in". However, the problem is the speaker was probably difficult find the proper word, so he made FL with expresion " $u h$ ". In (d) like (c), the speaker was intended to utter "there is an..." but in the beginning of the utterance he made an error by saying "that is one of" instead. She recognized that she made an error so immediately she repaired with new words that she wanted to utter but in the middle of producing word, she probably experienced difficult in finding proper words, so she made FL with an expression " $u h$ " before she found the proper word. The occurence of FL appear right after the speaker made FS. The occurence of FS, however, appears in the beginning of utterance. It is identificated that FS usually appeared in the middle of speech.

\section{Grammatical Error in Male and Female Learners}

The type of GE occurred 26 times in all the learners' speeches. The occurrence of GE was around the disfluency in using tenses, particles, and verbs. It appeared from the beginning of the speech to the last of the speech. Every learner had made GEs from the beginning to the last of speech. however, there are few number of GEs that occured in that occasion. The middle of the speech is the occasion that GEs often occured. It gradually increased in the minute of 0,25 and decreased at the minute of 1,0 . But the top of number GEs occured happened at the minute of 2,0 and began to decreased after that until the minut of 3,0 . In male learners its frequency is $6,87 \%$ or 48 times of occurrence, while in female learners $8,61 \%$ or 41 times of occurrence. This type occurred without any RVs conducted by the learners. It was probably that the learners did not realize that they had just made some disfluencys in grammatical rules. GE usually occurred along with the other disfluency types such as FL and RP. The examples of GE are in the utterance such as:
a. "it [is] make the other"
b. "... to heal [a] asthma"
c. "When I [go] to Canada lastyear"
d. "They can [to] take some effort..."

The example (a), it can be described that the speaker was supposed to say "it makes the other...", the proper sentence is the word "is" is supposed to omit from the sentence, so the proper utterance should be "it makes the other...". This can be typified that this error belongs to the grammatical error in verb. Like (a), the example (b) shows that the speaker said "..to heal a asthma", but the proper utterance is "..to heal an asthma". It is because the proper article should be " $a n$ ". In the example (c), like (a) it belongs to the error in verb, which the speaker said "when i go to Canada last year", but this utterance is in past tense so the proper utterance should be "when I went to Canada last year". In (d), it is different with other examples. The error is in the use of auxiliary "can" which word auxiliary never needs preposition word like " $t o$ ", so the proper word, word "to" should be ommited. So the proper word that the speaker say should be "they can take some effort..."

\section{The Dominant Type Made by Male and Female Learners}

In addition, in the research filler (FL) is the most dominant disfluency type produced in male and female learners. there are 445 filler occured in male and female speeches. It is also similar with Shriberg (1996) in Bortfeld et.al (2001, p.128) theory, it is stated that males produced more filler than females. Besides, the disfluency made by each male and female learners is different. The difference is about the number of disfluency they produced and the dominant disfluency type occured in their speeches. For the number disfluency made by male and female speeches is siignificantly different. In total, male produced 699 disfluency, whereas female produced 476 disfluency. 
Chart 1 The Dominant Type of Disfluency Made by Male Learners

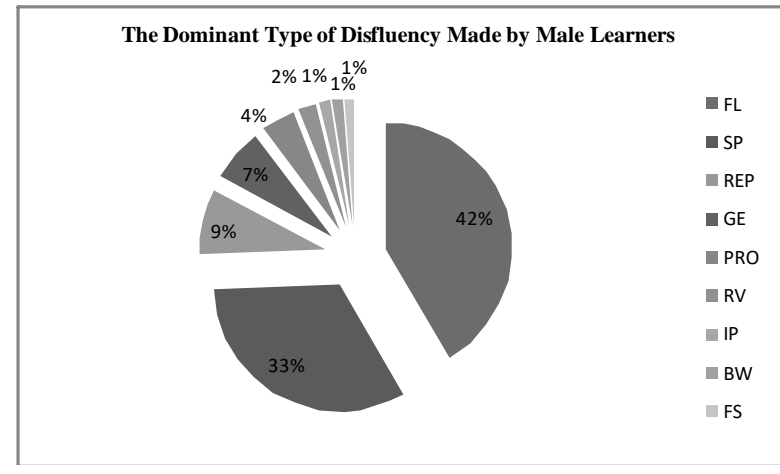

Chart 2 The Dominant Type of Disfluency Made by Female Learners

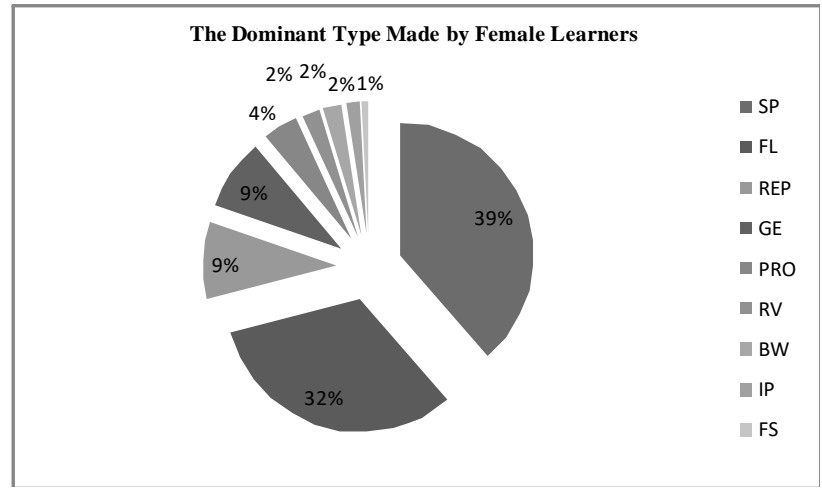

In addition in the dominant disfluency appeared in speeches, male and female is also different. The dominant disfluency type occured in males' speeches is filler (FL) which is 291 times or $41,63 \%$ in frequency, whereas in females' speeches is silent pause (SP) which occured 184 times or $38,66 \%$ in frequency.

\section{Factors Causing the Difluency Made by Male and Female Learners Cognitive factors}

Cognitive factor is the most reason that was said by disfluency made by male and female learners. the writer categorizes the cognitive factor found in the study into two categories, they are lack of vocabularies and lack of grammar.

\section{Lack of Vocabularies}

This factor is the most reason the learners said in the interview, averagely, the problem that they face is vocabularies. Some learners say they do not have enough vocabularies of English. So that when they wanted to utter something, they were difficult to say in English. In the end, they made disfluency in their speech because they were too much thinking finding the translation in Engslih. As the writer asked about the reason they were difficult to utter in their speech, one of learners said, "Apa ya... waktu saya mau ngomong itu, saya ga tau bahasa Inggrisnya apa, jadi ya gitu kebanyakan mikir" And another learners proposed his reason, "Mungkin saya terlalu banyak mikir arti dari kata ini dan itu kali he he he..."

As stated above, the confession of the learners factor of mastering vocabularies becomes the reason the learners made disfluency in speech. But this is not the one and only that becomes the factor causing the disfluency in male and female learners in Kampung Inggris Semarang. 


\section{Lack of Grammar}

Besides mastering vocabularies, grammar is another reason that becomes the reason why learners made fisfluency in their speech. Grammar in this case is structuring sentence in their mind (while thinkng) before they utter verbally. As one of the learners said, "Sebenernya saya tahu artinya tapi saya kadang bingung ini pengucapannya seperti apa dan bagaimana..." Or another learner confessed the reason, "Saya tidak paham cara nyusun kalimatnya, jadi waktu mau bicara mikir dulu nyusun kalimatnya gimana gitu..."

Some learners proposed this factor as the reason they made disfluency. Apparently, some learners are still fussing about grammar in speaking skill.

\section{Familiar with the Topic}

This is one of the reason that proposed by some learners, such as like one learners argued that she was not familiar with the topic, "Kalau ada waktu lebih banyak saya mungkin bisa, ya mungkin karena belum paham sama topik yang saya ambil sih."

In addition, there is one learner that also claimed that he could not speak fluently, "Ga terlalu mamahami topiknya, jadi sempet blank... (laugh)." The reason that topic becomes the factor causing disfluency in speech. According to the findings, familiar to the topic becomes the factor causing the disfluency made by male and female learners in the study.

\section{Affective Factors}

There are three categories that belongs to the affective factors. This factor is related to the problem faced by the internal factor made by the learners itself besides cognitive factors. The affective factors that the writer provides are nervous, habit, and confidency.

Nervous

Some learners said they were getting nervous when they were in front of people. This becomes the third reason why some speakers cannot speak very well. Sometimes they made som disfluency in their speech. They calimed that nervous is the reason disapperness of their material that have been prepared yet. As on elearner said, "Ga tau mas hehehe.. saya gugup pas bicara di depan, apalagi pas ngomong bahasa inggris, makanya saya belajar di sini.. (laugh)"

Or another laerner who honestly confessed the reason she produced difluency, "Iya pas di depan itu rasanya nervous, jadi sempet blank juga tadi."

According to the confession above, some learners produces disfluency because they were getting nervous while delivering the speech.

\section{Habit}

Habit is the forth reason that some learners proposed to the writer in the interview. This habit means that the time of using Englsih in their daily activity. Some learners said that not every day they speak English, as this learner said, "Karena saya jarang nggunakan bahasa Inggris, jadi saya masih kaku kalau mau bicara pakai bahasa Inggris."

This becomes the reason of learners in claiming they could not speak English very well so they made some disfluency in their speech.

\section{Confidency}

This factor appears in some learners when they were answered the question about the reason that the learners was difficult to utter what they wanted to say. Some learners said that they are afraid of making mistakes in uttering some words in English. They do not have the confidency to speak in English. As one of learners said, "Saya takut salah ngomong waktu mau ngomong bahasa Inggris"

Or another learner that confessed the reason why he cannot speak very well, "Ga pede, mas saya... takut salah. Mungkin gitu alasannya." It identifies that there are some learners are still afraid of making mistakes in speaking English. This cannot avoid it, because one to another person is different. There are some typical persons who are still afraid of making mistakes in speaking even it is in mother language. 


\section{DISCUSSIONS}

The findings showed that both male and female learners produced several disfluency types, such as filler, silent pause, repetition, prolongation, grammatical error, revision, incomplete phrase, broken word, and false start. Male learners produced same disfluency type as female learners. There were only seven types that were produced by both male and female learners. It is in line with the Clark and Wasow's (1998) theory that those types occurred in normal speakers. Reviewing the disfluency found in the study, the writer can conclude that the reason why learners made disfluency because it is related to the word production. Disfluency as Clark and Wasow (1998) state, if speakers find it difficult to plan major constituents, they should have problems starting them up, and they do (Salesky, et al., 2019). They are most likely to pause before the first word of such units, next most likely just after the first word, and less likely after that. The theory that Clark and Wasow (1998) propose there are several disfluency that usually occured in speech they are filler, silent pause, repetition, hesitation which includes revision, incomplete phrase, and broken word, prolongation, false start, slip of tongue and grammatical error. However, all the type of disfluency that Clark and Wasow (1998) propose are found in the current study, except slip of tongue. The current study never found this kind of disfluency in male or female learners' speeches that the writer studyed. In addition, the assumption that the writer provides why slip of tongue did not appear in learners' speeches is just coincidency. Another hypothesis the writer proposes that the studyed learners is about the learners lack of lexical storage. Altıparmak, A., \& Kuruoğlu, G. (2018) states that slip of tongue rlates to the lexical storage if it happens in L2 language production. Eventhough the current study is not for the L2 but it can indicates that English does not become the L1 or mother language. The writer's hypothesis is about lexical storage, it means that the learners in the current study have lack of vocabularies and grammar, it does not close the possibility that there is no mistake or error in producing word while the speaeker utter because there is no lexical storage they own.

\section{Dominant Type of Disfluency Made by Male and Female Learners}

The dominant disfluency occured in male and female is different. As the description before, male learners produced more filler than female learners. the number shows that male learners produced 291 fillers than female learners that produced only 154 fillers. This would be interesting because this is same as Shriberg theory that says men produced more filler than women (Shriberg, 1996). It is proven by this current study that male learners produced more filler than female learners. Bortfeld et.al (2001) also state, "Men produced 2.57 more disfluencies per 100 words." However, female learner produced more silent pause in their speeches, but this does not make the number of silent pause made by female learners produced more than male learners. The number of silent pause made by male learners does still produced more than female learners. According to the explanation above, it can be concluded that the current study is in accordance with the theory and the previous study that male produced more disfluency than female.

In the current study, there are some points that can be related to the theory that Bortfeld et.al proposes especially about the disfluency made by male and female learners. Bortfeld et.al's (2001) study shows that male produced more disfluency than female. They said that the main contributor to the Bortfeld's study was filler. It is same with the current study, this study male learners produced more disfluency and the dominant disfluency is filler.

Besides, Bortfeld et.al also argued that topic also influenced the disfluency. However, the findings that found in the current study is also similar. It can be found in the curent study that familiar with the topic is one of factors causing disfluency. Bortfeld et.al (2001) state that topic is another characteristic that may cause the planning load of utterances to vary. In the current study, the writer presumes that familiar with the topic 
that has been given to the learners before they deliver it may cause the disfluency because they were trying to plan load of the utterance.

\section{The Difference of Disfluency between Male and Female Learners}

There are three differences of disfluency made by male and female learners that is the number of disfluency, the dominant disfluency occured in speech and the number of learners who made more factors in affecting disfluency. The result says that male learners produced more disfluency than female learners. moreover, the dominant disfluency appeared in their speeches is also different. While male learners produced more filler, female learners produced more silent pause although the number of silent pause occured more than filler. Number of filler produced in female learners is still less than the number of silent pause made by male learners.

The dominant disfluency occured in male and female is different. As the description before, male learners produced more filler than female learners. the number shows that male learners produced 291 fillers than female learners that produced only 154 fillers. This would be interesting because this is same as Shriberg theory that says men produced more filler than women (Shriberg, 1996). It is proven by this current study that male learners produced more filler than female learners. Bortfeld et.al (2001) also state, "Men produced 2.57 more disfluencies per 100 words." However, female learner produced more silent pause in their speeches, but this does not make the number of silent pause made by female learners produced more than male learners. The number of silent pause made by male learners does still produced more than female learners. According to the explanation above, it can be concluded that the current study is similar to the theory and the previous study that male produced more disfluency than female.

Besides, the data taken from the interview, statistically male learners confess they do not master the vocabularies and grammars. The difference between male and female in producing disfluency perhaps makes some possibilities that can be researched further. By seeing the factors taken from the interview in this research, male learners make factors that affect the disfluency in their speeches than female learners. However, this case is absolutely supposed to be researched further why males make more disfluency.

\section{Factors Causing the Difluency Made by Male and Female Learners}

Comparing to the Muamaroh's study, Muamaroh (2013) \& Khaliq, et al., (2017) proposes some factors causing speaking is not very well to utter, she argued it is referred to confidency of the speaker. The factors are mastering of vocabularies, structure and material, teacher's behavior in class, the atmosphere of the class while the speaker speaks, the habit that the speaker speak Englsih in his/her activity, working a group or individully. These factors are actually similar to the current study that are found in the study. In the current study, the writer found the factor that have been stated by Muamaroh's (2013) study, such as the mastering vocabularies, grammar and material or topic which is categorized by the writer as cognitve factors. In addition, in the current study also appears some factors such as confidency, habit, and nervous which are categorized them as affective factors. According to the current study, there are some points that can be highlighted in the theory and the findings that can be related to the Muamaroh's (2013) study . Apperantly, there are still few relation with the Muamaroh's study especially in factors causing disfluency in learners speeches.

In the current study cognitive factors like lack of vocabularies, lack of grammar is the most reason that the learners proposed. This factor is related to Muamaroh (2013) states that mastering vocabularies, structure and material can improve their confidency in speaking English. Besides, the topic that the learners familiar with is also related to the disfluency that the learners produced in their speech. However, in the study, there are some learners claimed that the topic that they refer is not so familiar although they have chosen by themselves. Familiar with the topic its self is also the one of the reasons Vural's (2008) proposes. Vural (2008) states that speakers are more fluent when speaking on a 
concrete topic then when speaking on an abstract topic, since concrete topics are shorter than abstract topics.

Also, the reason of habit is also proposed by Muamaroh (2013), she proposed that having getting used to speak English is one of the factor to be fluent in Englsih. "Therefore it was reasonable when some students suggested the teacher use English and Indonesian mixed in the class. This might be because they still felt it difficult to understand the teacher's explanation if he/she only used English" (Al-Sobhi, \& Preece, 2018; Abrar, et al., 2018). Not only those factors, other factors such as getting nervous and confidency in this current study, is similar fator that Muamaroh (2013) states in her study. She (2013) argued that the more the students practise speaking English, the more they improved their confidence.

\section{CONCLUSION}

There are a lot of findings that has been found in th research and it should be researched further because there are some cases remain in the research such as the slip tongue that cannot find in the research and the gestures that the learners made when they produce the disfluency and the reason why male learners more produce disfluency and factors affecting disfluency than female learners.

The suggestion are refering to readers, English learners, English teachers, and other researchers. For the readers, this study will be the new knowledge about disfluency based on the gender i.e male and female. However, there are some researches that focus on disfluency in male and female, thi sstudy will be one of variety and knowledge to the readers. For the English Learners, this study may also be very useful for English learners to know the deficiency of their speech, in this case is based on the gender, male and female EFL learners. For the English teacher, this study is hoped to know the difficulties in English speaking and to be an input in giving information about student's disfluency in their speech. It is also to help teachers know the characteristics of disfluency type made by the EFL learners so the teacher can prevent the difficulties in teaching English especially in teaching speaking. And for the other researchers, It is hoped to be the reference in conducting the research about disfluency based on gender. However, there is some cases remain in this research that are needed to do further research $n$ the future. For example, the researcher hopes to other research to do the research why in some case there is no disfluency that is never produced in this research is slip of tongue. Also there a $\backslash$ is finding that the researcher found $n$ the research i.e. gestures. In the research the researcher does not discuss further about the gestures that the learners made while they produced disfluency in their speeches.

\section{ACKNOWLEDGMENT}

This research was funded by the Budget Allocation of Universitas Maritim AMNI Semarang in the fiscal year of 2019 and stated in the Decree of the Rector of Universitas Maritim AMNI Semarang Number 131 Year 2019. This research was categorized into Individual Research.

\section{AUTHOR CONTRIBUTION STATEMENT}

The authors had participated in the research and approved the final version of the manuscript

\section{REFERENCES}

Adams, M. R. (1990). The demands and capacities model I: Theoretical elaborations. Journal of Fluency Disorders, 15(3), 135-141. https://doi.org/10.1016/0094730X(90)90014-J 
Abrar, M., Mukminin, A., Habibi, A., Asyrafi, F., \& Marzulina, L. (2018). " If our English isn't a language, what is it?" Indonesian EFL Student Teachers' Challenges Speaking English. The Qualitative Report, 23(1), 129-145. Google Scholar

Altıparmak, A., \& Kuruoğlu, G. (2018). An Analysis of Speech Disfluencies of Turkish Speakers Based on Age Variable. Journal of psycholinguistic research, 47(3), 699-718. https://doi.org/10.1007/s10936-017-9553-4

Al-Sobhi, B. M. S., \& Preece, A. S. (2018). Teaching English speaking skills to the Arab students in the Saudi school in Kuala Lumpur: Problems and solutions. International Journal of Education and Literacy Studies, 6(1), 1-11. http://dx.doi.org/10.7575/aiac.ijels.v.6n.1p.1

Bortfeld, H., Leon, S. D., Bloom, J. E., Schober, M. F., \& Brennan, S. E. (2001). Disfluency rates in conversation: Effects of age, relationship, topic, role, and gender. Language and speech, 44(2), 123-147. https://doi.org/10.1177\%2F00238309010440020101

Byrd, C. T., Bedore, L. M., \& Ramos, D. (2015). The disfluent speech of bilingual SpanishEnglish children: Considerations for differential diagnosis of stuttering. Language, speech, and hearing services in schools, 46(1), 30-43. https://doi.org/10.1044/2014_LSHSS-14-0010

Clark, H. H., \& Wasow, T. (1998). Repeating words in spontaneous speech. Cognitive psychology, 37(3), 201-242. https://doi.org/10.1006/cogp.1998.0693

Fauziati, Endang. (2013). Psycholinguistics: An Introduction. Surakarta: Era Pustaka Utama.

Johnson, Wendell. (1961). Studies of Speech Disfluency and Rate of Stutterers and Nonstutterers. The Journal of Speech and Hearing Disorders Monograph Supplement 7. 1-5. PDF file. Google Scholar

Khaliq, A., Zaidi, N. A., Pathan, Z. H., \& Ahmed, N. (2017). Factors Causing Hurdles in Speaking English among College Students of Quetta. Alburz, 9(1), 246-258. Google Scholar

Lickley, R. (2017). Disfluency in typical and stuttered speech. Fattori sociali e biologici nella variazione fonetica-Social and biological factors in speech variation. http://dx.doi.org/10.17469/02103AISV000019

Miller, J.F., Long, S., McKinley, N., Thormann, S., Jones, M. A., \& Nockerts, A. (2005) Language Sample Analysis II: The Wisconsin guide. Madison, WI: Wisconsin Department of Public Instruction.: 1-8. PDF file. Google Scholar

Muamaroh. (2013). Improving Indonesian University Learners' Spoken English Using Group Work and Cooperative Learning. Dissertation of Doctor of Philosophy. Charles Darwin University. Google Scholar

Poulisse, Nanda. (1999). Slip of Tongue. Speech Disfluency in First and Second Language Production. Studies in Bilingualism vol 20. Amsterdam: John Benjamins B.V Publication. GoogleScholar

Sadri Mirdamadi, F., \& De Jong, N. H. (2015). The effect of syntactic complexity on fluency: Comparing actives and passives in L1 and L2 speech. Second Language Research, 31(1), 105-116. https://doi.org/10.1177\%2F0267658314554498

Salesky, E., Sperber, M., \& Waibel, A. (2019). Fluent translations from disfluent speech in end-to-end speech translation. arXiv preprint arXiv:1906.00556.

Shriberg, E. (1996). Statistical language modeling for speech disfluencies. Acoustics, Speech, and Signal Processing, 1996. ICASSP-96. Conference Proceedings., 1996 IEEE International Conference on, 1. Google Scholar

Tumanova, V., Conture, E. G., Lambert, E. W., \& Walden, T. A. (2014). Speech disfluencies of preschool-age children who do and do not stutter. Journal of communication disorders, 49, 25-41. https://doi.org/10.1016/j.jcomdis.2014.01.003

Vural, Erkan. (2008). Disfluency in Second Language: A Quantitative Study On Turkish Learners Of English. Masters Dissertation. The Middle East Technical University. Google Scholar 
Yu, L. (2019). Causes of disfluency in Chinese L2 speech. Language Teaching and Linguistic Studies, 03.. Google Scholar

\section{Copyright Holder :}

(C) Abimanto, D., Hidayah, Y., Halimah, H., \& Hasyim. U. (2021).

\section{First Publication Right :}

(C) Anglophile Journal

This article is under:

CC BY SA 